\title{
A encruzilhada do reconhecimento no direito natural do Fichte de Jena: política e representação da alteridade
}

\section{Faustino Oncina Coves}

Tradutor. Vasco de Jesús

\section{OpenEdition}

\section{Journals}

Edição electrónica

URL: http://journals.openedition.org/ref/453

DOI: $10.4000 /$ ref.453

ISSN: 2258-014X

\section{Editora}

EuroPhilosophie Editions

Refêrencia eletrónica

Faustino Oncina Coves, «A encruzilhada do reconhecimento no direito natural do Fichte de Jena: política e representação da alteridade », Revista de Estud(i)os sobre Fichte [Online], 7 | 2013, posto online no dia 30 dezembro 2013, consultado o 08 setembro 2020. URL : http://

journals.openedition.org/ref/453 ; DOI : https://doi.org/10.4000/ref.453

Este documento foi criado de forma automática no dia 8 setembro 2020

(c) EuroPhilosophie 


\section{A encruzilhada do reconhecimento no direito natural do Fichte de Jena: política e representação da alteridade}

\section{Faustino Oncina Coves}

Tradução : Vasco de Jesús

\section{NOTA DO AUTOR}

Este trabalho surgiu no âmbito do projecto de investigação "Hacia una Historia Conceptual comprehensiva: giros filosóficos y culturales" (FFI2011_24473) do Ministerio de Economía y Competitividad, e foi concluído durante uma estada no Zentrum für Literatur-und Kulturforschung e na Technische Universität de Berlim graças ao apoio do Vicerrectorado de Investigación y Política Científica da Universitat de València. Quero manifestar o meu agradecimento aos meus anfitriões em Berlim: Ernst Müller, Falko Schmieder e Thomas Gil.

1 Provavelmente tereis [já] ouvido falar do escândalo que provocou na Alemanha o livro de uma figura pública, antigo senador de finanças na coligação entre o SPD e Os Verdes pelo Estado de Berlim, membro conspícuo do Partido Social-Democrata [alemão] a quem foi movido, sem êxito, um processo de expulsão desse mesmo partido, dirigente do afamado Banco Central alemão, ou [melhor], ex-dirigente - pois que foi apresentado um requerimento ao Presidente da República para que fosse afastado desse Olimpo do euro. Para além de nos brindar com uma definição genética dos judeus no seu bestseller Deutschland schafft sich ab (A Alemanha derroga-se, suprime-se, desfaz-se), que desde Agosto de 2010 (ano da sua publicação) tem sido sucessivamente reeditado, Thilo Sarrazin - é esse o nome da figura aludida - serviu manchetes como esta, de bandeja, à imprensa cor-de-rosa ou sensacionalista: “Árabes e turcos só servem para vender fruta 
e hortaliça"1. Foi ao abrigo do vendaval causado por este campeão de vendas que assistimos à solene notícia da morte do multiculturalismo, proclamada com ares nietzscheanos pela Chanceler Angela Merkel perante a juventude Democrata-Cristã no Outono de 2010. ("Multikulti ist tot"). Ainda que obviamente não se deva confundir uma coisa com a outra, o certo é que ambos os acontecimentos partilham um fundo comum que, claro está, não é exclusivo da Alemanha. O Primeiro-Ministro inglês, David Cameron, entoou o mesmo requiem um ano depois da sua colega germana. Trata-se da celebérrima dialéctica «nós - eles», que ao longo da história assumiu diversas roupagens, algumas verdadeiramente sinistras: «nativos-bárbaros», «amigosinimigos», «sobre-humanos-infra-humanos»,... Entre os nichos culturais tradicionais destas dicotomias destaca-se explícita ou implicitamente o fichteanismo. Johann Gottlieb Fichte proveu munição abundante a esta retórica de antagonismos beligerantes nos seus berlinenses Discursos à nação alemã, publicados em $1808^{2}$. Sem dúvida que é primordialmente uma tendenciosa interpretação ideológica da última fase do seu pensamento aquela que instiga a perseguição ao estrangeiro - se bem que tão-pouco na sua fase jacobina (nas suas Contribuições de 1793 destinadas a defender a Revolução Francesa contra as hostes reaccionárias) [Fichte] se abstinha de escançar afirmações abomináveis que avolumaram a antologia de frases feitas do anti-semitismo:

"Que se pode esperar de um povo..., que vê em todos os outros povos os descendentes daqueles que os expulsaram da sua pátria, amada até ao fanatismo...; que é excluído dos nossos repastos, dos nossos prazeres e do doce intercâmbio de alegria entre os corações pelo vínculo mais forte que a humanidade possui, pela sua religião...? [...].

2 Longe destas páginas... o hálito envenenado da intolerância! Aquele judeu que consegue chegar até ao amor universal da justiça, dos homens e da verdade apesar das firmes e inclusivamente intransponíveis trincheiras que encontra diante de si é um herói e um santo. Não sei se os terá havido ou se os há. Estarei disposto a acreditar nisso mal os veja. [...]. Devem gozar dos direitos do homem, mesmo quando não no-los reconheçam, pois são homens, e a sua injustiça não nos autoriza a comportarmo-nos como eles. [...]. Mas quanto a conceder-lhes os direitos civis, eu, pelo menos, não vejo outro remédio senão cortar-lhes a cabeça a todos uma noite destas e substituí-la por outra em que já não haja nem uma só ideia judaica. E quanto a protegermo-nos deles, não encontro outra solução senão conquistar a sua terra prometida e mandá-los todos para lá”3.

3 Este anti-semitismo num revolucionário fervoroso está em sintonia com outra pérola asquerosa de Kant: "a mestiçagem não fez senão degradar a boa raça sem elevar proporcionalmente a má (do que é testemunho, por exemplo, o cruzamento de americanos com europeus ou o destes com a raça negra)" ". [É] claro que não descobrimos nada [de novo] ao atestar que nem tudo é luminoso no Iluminismo e que a drenagem dos preconceitos não funcionou a pleno rendimento, quer pela sua incapacidade para eliminar os antigos, quer pela sua capacidade para gerar novos [preconceitos].

4 Entre a fase em que Fichte era um viajante incansável que, destituído academicamente, atravessava fronteiras em busca da mera subvenção que lhe permitisse entregar-se à filosofia e a sua estada em Berlim na altura em que os Estados alemães se esgarçavam perante a pujança de Napoleão e se começava a forjar a Universidade humboldtiana, despontam os anos gloriosos do seu magistério em Jena. Num quinquénio (de 1794 a 1799), desenvolverá uma filosofia da intersubjectividade pouco frequentada e que não 
casa com a salmodia nacionalista e xenófoba com que sempre se salpicam as notas biográficas deste autor multifacetado.

5 A Universidade de Jena é hoje uma das universidades alemãs mais pequenas, mas no início do século XVIII era, com 1800 estudantes, a maior de todas. Contudo, seguiu-selhe um período de decadência em que esteve à beira do colapso. Tinha-se tornado antiquada e o número de matriculados caiu vertiginosamente. Há que agradecer o seu renascimento ao ducado de Sachsen-Weimar-Eisenach, que se esforçou por contratar talentos promissores.

Mas não eram só as circunstâncias políticas, o avanço da roseta revolucionária até às margens do Reno - também as monetárias traziam a Universidade desassossegada. Atraíram-se jovens brilhantes para ocupar cátedras mas não podia oferecer-se-lhes nada para conservá-los. Quando se tornavam célebres, partiam para uma Universidade mais bem dotada. Foi assim que Jena perdeu Reinhold, que granjeou a fama de ser o delfim de Kant.

7 Fichte foi o seu sucessor a partir de 1794, embora se soubesse que era o autor de panfletos radicais que apareceram após a decapitação de duas cabeças reais (as de Luís XVI e Maria Antonieta) e quando boa parte do estamento douto, assustado pelo rumo dos insurrectos, começou a cantar a palinódia. Os estudantes acudiram a rodos. As suas aulas estavam repletas e deparava-se amiúde com um contingente de 500 pessoas. Eram os dias do romantismo temporão, que ali fixou a sua sede, convertendo a pequena Jena numa metrópole espiritual. Em 1801 dissolveu-se essa Atenas germânica que gostava de fichtear - um neologismo que Schlegel e Novalis cunharam como sinónimo de filosofar.

8 Mas antes desencadeou-se a querela do ateísmo. Fichte despertou receios desde o início. Já em 1794 se difundira o rumor de que ensinava publicamente que daí por 20 ou 30 anos já não haveria nem reis nem príncipes. Em 1798, o filósofo foi acusado de propagar blasfémias e em seguida despedido. Não ignorava os verdadeiros motivos [por trás] da sua perseguição: "Para eles, sou um democrata, um jacobino [...]. Não é o meu ateísmo o que eles perseguem judicialmente, mas sim o meu democratismo" (GA I/6, 72-73).

9 Em 1799, quase todos os estudantes assinaram uma petição: "Com ele (Fichte) perdemos uma das principais razões da nossa permanência aqui”. No prazo de um ano, o número de matriculados minguou $41 \%$. O êxito dos seus cursos dificilmente tem paralelo. A sua geração representa um ponto de inflexão na didáctica universitária que [em vez] de se centrar na exegese de livros canónicos passa a ser forja das cosmovisões elas mesmas, encarnando paradigmaticamente o axioma humboldtiano da unidade entre docência e investigação. A aura de Fichte deve-se à sua atitude provocante e até mesmo provocatória, particularmente sedutora para os discentes, mas antes do mais às suas prelecções e [aos seus] seminários. Na sua cátedra congregavam-se ouvintes vindos de diversos estados alemães e estrangeiros. Esta personalidade e o seu verbo fascinavam ao mesmo tempo que obrigavam a uma concentração extrema. Enquanto alguns se entusiasmavam com ele, outros troçavam das palavras monstruosas com que fornia a sua linguagem. A partir do Inverno de 1975, consagrou vários semestres à sua filosofia do direito - e o seu livro Fundamento do direito natural segundo os princípios da Doutrina da Ciência foi elaborado não só no calor do debate com os clássicos e os contemporâneos mas também no fragor da sua discussão com os alunos.

10 A etapa de Jena constitui um manancial das incertezas e dos enganos que ainda hoje nos melindram, fixando limites de que ainda não nos afastámos e dentro dos quais não aprendemos ainda a estar. A partir dos princípios da Doutrina da Ciência (1794) foi 
primeiramente deduzido o destino do homem como sujeito jurídico; depois como persona moralis. A elucidação do homem enquanto ser religioso ficou truncada pela querela do ateísmo, tal como a polémica da revista As Horas, com Schiller, impedira um desenvolvimento tranquilo do homo aestheticus, e Fichte suscita [ainda] a eventualidade de um homo politicus e oeconomicus. 0 opus magnum desse quinquénio esplendoroso é o aludido Direito Natural que compreende dois grandes capítulos e dois apêndices controversos sobre o direito da família e o direito dos povos. Os capítulos abordam a estrutura interna da intersubjectividade, uma questão vinculada ao problema do fundamento da representação na sua dupla acepção de figura da consciência e de delegação política.

11 A alteridade é examinada por Fichte de diversas formas sem que se demore em todas por igual. Pode referir-se ao outro (Natureza), a outrem (Sociedade) ou ao Outro (Deus). As investigações sobre o reconhecimento dos outros estão no centro do Direito Natural. É a representação de um Não-Eu racional, de um alter-ego [sic] -esse estranho familiar, essa afinidade intrusa- uma mera figura da consciência ou tem [essa representação] um correlato real? Qual é o critério de demarcação entre o mundo natural e o social?

0 modo de entender o fundamento da relação da representação com o objecto delimitará duas posições antagónicas, o dogmatismo e o idealismo, pois «quem quer fazer da representação aquilo que genericamente tem lugar na alma humana não pode, se é [que é] consequente, saber nada de liberdade... É forçoso que se torne num fatalista empírico!» (GA III/2, 28). Fichte enfrenta a reconstrução do sistema kantiano pressupondo o ressurgimento do cepticismo justamente no seio das Críticas de Kant. 0 rito iniciático de qualquer filosofia credível é a resistência ao cepticismo, isto é, à divergência entre a espontaneidade da subjectividade e o que é dado pela sensibilidade, à enigmática manifestação sensível da razão e à incapacidade da filosofia para se tornar sistema, sempre dependente de um dualismo ignoto entre liberdade e coisa-em-si.

o direito emerge como um dos vasos comunicantes entre a teoria e a prática, entre a consideração do mundo enquanto dado e a sua interpretação tal como «deve ser feito por seres racionais», indaga as condições de possibilidade para que a liberdade ela mesma germine na natureza. A liberdade concretiza-se nos indivíduos mediante a limitação do seu exercício empírico; já a lei jurídica ("tenho de limitar a minha liberdade pelo conceito da liberdade dos outros") pressupõe a elucidação da experiência da alteridade, uma incursão na "dedução da nossa convicção sobre a existência de um mundo sensível exterior a nós", isto é, na "questão sobre o fundamento da realidade dos objectos» (GA I/3, 337-348). O objecto pode ser um sujeito, um tu - e fundamentar a objectividade da representação significa então fundamentar a intersubjectividade. É preciso explicar como é que um Não-Eu, um alter-ego [sic], não anula a liberdade, antes a desperta, como é que a consciência do objecto, que aqui é um outro sujeito, não destrói, antes requer a autoconsciência. 0 embate que inaugura esta interacção há-de ser uma exortação à actividade, uma determinação à autodeterminação. $\mathrm{O}$ Eu é exortado passivamente a partir de fora; mas a exortação convida a "re-agir". Esta troca de apelos a agir implica uma delimitação do âmbito de actividade de cada Eu para evitar que essa interpelação mútua degenere em intromissão. A dedução do conceito de direito irrompe então como condição de possibilidade da objectividade social.

Desta maneira, a individualidade monádica, robinsoniana, do Eu abre-se a uma dimensão interpessoal até se converter no conceito recíproco de reconhecimento segundo o qual os seres livres racionais se tratam entre si como iguais. Se a relação 
jurídica regula esferas de liberdade, o respeito por estas esferas depende da sua identificação sensível, de uma fenomenologia da liberdade:

«Como é que chegamos a estender o conceito de racionalidade a alguns objectos do mundo sensível e a outros não? [...] Kant diz: age de tal forma que a máxima da tua vontade possa ser princípio de uma legislação universal». Mas quem é que deve pertencer ao reino que se rege por esta legislação e tomar parte na protecção que ela assegura? [...] Pois como sei eu que determinado objecto é um ser racional, se a protecção dessa legislação concerne ao europeu branco ou também ao negro, ao homem adulto ou também à criança, ou se porventura não poderia inclusive dizer respeito ao fiel animal doméstico? Enquanto esta questão não estiver resolvida, aquele princípio, com toda a sua excelência, não tem [nem] aplicabilidade nem realidade» (GA I/3,380).

15 A criteriologia da alteridade possui um enorme alcance. Em primeiro lugar, sem tais critérios o direito é completamente estéril, pois o seu objecto permaneceria impreciso e [o direito] resultaria inaplicável. Com a moral sucede outro tanto. Há que discernir o que é característico do fenómeno do humano perante o resto dos fenómenos naturais para tratá-lo sempre como um fim e nunca como um meio, para traçar uma linha divisória entre o imperativo categórico e o técnico (e, por conseguinte, para reflectir sobre as tensões [que se verificam] entre uma filosofia social e uma filosofia da natureza, entre uma ética humana e uma ecológica). Em segundo lugar, a escolha do critério de demarcação tem consequências éticas e jurídicas importantes, como testemunham a referência à servidão, o racismo e o paternalismo. [Tal criteriologia] abre caminho às críticas modernas da coisificação, definida como aquela atitude que consiste em tratar os demais seres humanos, as próprias faculdades anímicas e as realidades naturais como meras coisas disponíveis, manipuláveis e comercializáveis. A reificação erige a mercadoria a protótipo de todas as formas de objectividade e de subjectividade. Em terceiro lugar, de se conseguir apreender com êxito a especificidade do fenómeno do humano depende não só a elaboração de uma epistemologia do direito mas também [a elaboração de uma epistemologia] das ciências humanas em geral. Só com a descoberta de critérios capazes de revelar a presença da liberdade no mundo sensível se conseguirá um estatuto autónomo para aquelas ciências cujo objecto não está subordinado às leis do determinismo ${ }^{5}$.

16 Fichte inclina-se para a corporeidade enquanto traço visível da liberdade. A sua contemplação leva-nos a manter uma relação de comunicação recíproca com quem partilha [connosco] a mesma figura (uma comunicação que também pode ser veiculada através da linguagem, como comprova o escrito que consagra a este tema em 1795). Um olhar cúmplice, o entendimento instantâneo de uns olhos noutros é a ambrósia do reconhecimento simétrico, a sensação experimentada em uníssono de estar a ver-se ao espelho que nos desvela como almas gémeas, como acção e reacção. É o corolário de uma investigação em que está em jogo a aplicabilidade do conceito de direito, a identidade do sujeito jurídico.

O corpo articulado do homem possibilita-lhe movimentos não dirigidos à, nem pela reprodução da espécie. O movimento em direcção a metas não impostas pela reprodução é um traço que temos em comum com os animais, mas o catálogo humano de movimentos não está à mercê do instinto. Também os autómatos estão programados, não dispõem de um reportório infinito de movimentos - pelo contrário: a sua iniciativa está diminuída. A esfera humana de movimentos [, porém,] é potencialmente infinita, "in-definida". Pelo que o critério do que é humano não é a mera organização, nem a mera articulação, antes um corpo organizado e articulado de 
tal maneira que é capaz de movimentos livres indeterminados, por inventariar. Sem tal criteriologia, as máximas da moralidade e as leis jurídicas mostram-se impotentes para fixar os seus domínios e podem coonestar práticas políticas ilegítimas. A forma regiminis, a tarefa de produzir uma constituição política, não pode passar ao largo deste dado sob pena de se truncar a aplicação do direito.

Hoje em dia advoga-se um paradigma do reconhecimento ${ }^{6}$ em vez de um [paradigma] da tolerância basicamente por dois motivos. Em primeiro lugar, a tolerância pressupõe um certo desdém ou menosprezo. No fundo, significa suportar, aguentar, e encerra sempre uma desvalorização velada. Podem permitir-se ser tolerantes e, portanto, deixarem discricionariamente de o ser, os poderosos, a maioria ante a minoria. Algo muito diferente sucede com o reconhecimento, que assenta na reciprocidade, isto é, na igualdade jurídica e na equivalência moral. Em segundo lugar, a tolerância põe a tónica na ausência de conflitos, ao passo que as fricções são o elixir vital das sociedades modernas. O que hoje mantém unida uma sociedade não é só a comunidade de valores, são também as oposições e o esforço agónico. Enquanto a tolerância é assimétrica e procura atenuar conjunturalmente essa assimetria, o reconhecimento tem a simetria por vocação. Além disso, pode reivindicar-se tolerância sempre que haja razões para rejeitar uma idiossincrasia dissímil, um modo de vida a que se é estranho, irreconciliável com alguns aspectos das nossas convicções. Em tais casos, o preceito da tolerância exige que se assuma a responsabilidade pela relatividade da forma de vida própria para nos mostrarmos condescendentes e benévolos com a rival. A apresentação de contra-argumentos ao intolerante, por mais sólidos que sejam, não consegue provocar uma modificação no seu comportamento. O reconhecimento procura um contraforte legal. Só muito recentemente se aquilatou a contribuição do idealismo fichteano para este tema.

Em Fichte, a urbanização jurídica pertence às condições necessárias da autoconsciência porquanto não se concebe nenhum Eu sem reconhecimento mútuo, isto é, sem o lubrificante que é o direito. A relação de reconhecimento desenvolvida transcendentalmente carece ela mesma de uma obrigatoriedade incondicionada, porque o direito pretende emancipar-se da moral e constituir uma ciência autónoma. $\mathrm{O}$ conhecimento de que os outros são igualmente livres deverá ser articulado com um comportamento consequente não ditado pelo dever.

o próprio Fichte considera insuficiente a coacção lógica da relação jurídica, uma vez que a consequência - a ausência de contradição entre reconhecimento (epistémico ou cognitivo) e comportamento, entre conceitos e acções (passados e futuros) - depende da «liberdade da vontade» (GA I/3, 384s.). Há, sem dúvida, boas razões para se decidir em prol da coerência; mas tal decisão é, apesar disso, arbitrária, discricionária. A coacção lógica do pensamento é substituída pelo direito político, isto é, pela coaç̧ão policial de um Estado em que a divisão entre [os poderes] executivo, legislativo e judicial faz supor um entrave à realização da liberdade no mundo sensível. Tal separação enferma de indeterminação e, por isso, desgasta a eficácia da engrenagem jurídica. O executivo (exekutive) deve acumular as competências dos três poderes: legislativo, judicial e executivo no seu sentido mais estrito (ausübende). Kant, pelo contrário, mostra-se implacável com um parlamentarismo adulterado como o britânico, cujo [poder] legislativo se deixava tragar, isto é, corromper pelo [poder] executivo.

21 A constituição deve ser necessariamente representativa. O povo delega o exercício da soberania positivamente nos magistrados do executivo e negativamente nos éforos ${ }^{7}$. A 
um macropoder opõe-se um contrapoder. O eforato tem "o direito de controlar e ajuizar" o modo como o executivo administra o poder público. Compete a este órgão decidir quando é que se verifica um status necessitatis, o atropelo flagrante do direito por aqueles que se devem ater escrupulosamente a ele, e, mediante o anúncio de uma interdição, de uma ordem de suspensão de todas as atribuições governamentais, convocar a comunidade como tribunal. A democracia desenganada, [a que é] rejeitada, a directa, a parlamentar, acaba por se converter na tábua de salvação, se bem que simultânea e paradoxalmente [também] na autodestruição da democracia representativa, legítima. A esse conselho de "sábios e virtuosos", a essa corte de reis filósofos, cabe em missão transformar um agregado politicamente amorfo, uma massa exaltada de súbditos, num povo de cidadãos, numa comunidade de indivíduos responsáveis. A contrapartida da mobilização do eforato é a desmobilização do povo. Fichte admitirá mais tarde que o nó górdio do Direito consiste em dar resposta à pergunta relativa ao modo como surge "um público formado e capaz de formar-se a si mesmo", ou seja, na formação de um juízo autónomo [por parte] dos cidadãos, de um carácter e de uma dimensão públicos não cunhados por factores exógenos.

Não deixamos de esbarrar em aporias. A nomeação dos representantes assenta na [sua] virtude, mais do que no escrutínio dos votos, sendo frequentes os indícios de messianismo moral. Os éforos são os "grandes homens e os mais probos" (GA I/3, 456, cf. 451, 457). O sufrágio confirma a virtude; a assembleia referenda a probidade. 0 critério da maioria soma-se ao da pureza do coração.

Além disso, Fichte parte do egoísmo dos indivíduos e da falta de maturidade do povo para se ater à vontade geral. Daí que seja peremptório estabelecer estratégias de dissuasão e repressão de todos os seus desvios. Simultaneamente, a haver divergência entre os dois órgãos, [é] a comunidade [que] assume a responsabilidade de decidir qual o procedimento que é justo, [se] o dos executivos ou o dos éforos. 0 edifício greta pelos seus vícios construtivos. Se, por um lado, abomina a democracia directa pelo seu carácter despótico e antijurídico, por outro concede-lhe in extremis a virtualidade de resolver o eventual litígio entre o executivo e o eforato. Tal como censura um Reinhold incrédulo: é por ensalmo que um povo imaturo se torna maduro e na pedra de toque da legitimidade ${ }^{9}$.

Fichte cartografa a errância do conceito de vontade geral no país vizinho. Lá, a vontade geral é concebida como absolutamente constante, a priori, formal, e, atendendo ao abismo infinito entre o universal e o particular (ou agregado de indivíduos), o jacobinismo considera-a não como a expressão do povo que realmente existe, antes [como a expressão] de uma entidade pura e inalterável mais além da realidade popular. Este culto idolátrico de uma instância ideal permite dar um salto mortal mediante a ficção de uma vontade empírica que plasmaria a geral. Mas dado que há um incessante fluir inerente a toda a vontade empírica, [esta] não serve como sucedâneo da geral e a ficção redunda na arrogância de um despotismo que declara a sua vontade privada perfeitamente adequada à geral. Uma vez descartada esta ficção, entra então em cena a opção da vontade material do povo: «a vontade da maioria». Friedrich Schlegel pressentiu a violência intrínseca aos dois sentidos da legalidade revolucionária, pois na delimitação da vontade geral - tanto na [delimitação] pura quanto na empírica, na moral como na maioritária - desconfia-se de quantos não comunguem do credo jacobino ${ }^{10}$, expulsando-os e aniquilando-os pela sua inimizade com o povo (isto é, com a 
sua sanior pars). A lógica dicotómica deste discurso (povo/inimigos do povo) não é só [uma lógica] interna, é também extensível ao exterior (Estado republicano/ despótico).

Fichte admite a possibilidade de erro da vontade geral (nos seus representantes e na nação reunida), [de] que a sua decisão seja injusta materialiter. Não obstante, persevera na sua optimização por via da equação entre acto e lei. Uma única violação do direito é razão suficiente para dar azo à sua sistemática transgressão no futuro: a consequência férrea entre "os juízos e todo o procedimento dos que detêm o poder, [que] jamais se podem contradizer» (GA I/3, 445-446), possibilita estruturas legais repetíveis, susceptíveis de universalização.

26 A inconsequência conduz a uma ruptura abrupta do ciclo temporal do direito, do equilíbrio entre passado e futuro - leva, portanto, à revolução, que imita a aceleração característica do apocalipse perante o espetáculo de uma injustiça que chegou ao seu zénite, que se crê o Juízo Final, o tribunal infalível entre o poder executivo e o eforato, capaz de distinguir ${ }^{11}$ quem merece a glória de ser "custódio da nação», «éforo natural», e quem a desonra de um «rebelde», «mártir do direito». 0 rebelde, o mártir que, apesar de ter visões justas do futuro, não pode esperar por ele, precipita-se e precipita-o. [É] na sua incapacidade para apreciar o "ainda não» - na sua incapacidade de esperar - que reside a causa do seu martírio. Nesta voragem, paga o justo pelo pecador. Alterado o tempo do direito, é alto o preço que se paga ao salvar-se a constituição. Os éforos naturais, legítimos materialiter, procedem ilegitimamente formaliter contra os éforos e os executivos, legítimos formaliter. Este apelo ao povo é contrário ao Estado de direito, cuja "inapelabilidade é condição de toda a relação jurídica" (GA I/3, 446).

Hegel e Schelling puseram em relevo as sequelas deste complexo a que Fichte chama contrato de cidadania (compêndio dos contratos de propriedade, protecção e união), com o qual se desunha para esquematizar a soberania da vontade gera ${ }^{12}$ como momento regenerador da sociedade política. $O$ poder executivo e o eforato aparecem assim como dois representantes da vontade geral; com esta cisão pretende-se fazer prevalecer a sua integridade, a sua autodepuração; mas é o primeiro poder que detém de modo exclusivo a coerção e ser-lhe-ia fácil bloquear as funções do contrapoder (o seu trabalho de supervisão e a convocação do povo). Poderia uma profusão de contrapoderes assegurar a máxima equanimidade? A concretização do direito far-se-ia pagar com um regressus ad infinitum. Só a violência policial pode enlaçar as vontades individuais com uma liberdade universal. A marcação cerrada e ubíqua por parte do Estado é o único meio de ligar os átomos inertes que compõem o povo, de construí-lo artificialmente.

Eis o rosto de Jano do republicanismo fichteano. 0 jovem destituído tinha-se atrevido em 1793 a quebrar o pacto entre a monarquia e o círculo dos intelectuais, entre o poder e o Iluminismo. Com o recurso ao eforato em Jena, aspirava a voltar a selar essa aliança. Fichte cedeu a segurança do seu direito natural ao estamento douto. O contrapoder é privilegiado epistemicamente (dispõe de uma visão pristina do direito) e eticamente (integram-no os melhores, os mais sábios e virtuosos); é superior no que diz respeito ao conhecimento e à moral. Mas o poder estupidifica, "corrompe inevitavelmente o livre juízo da razão" (AK VIII, 369), diria Kant com ironia.

Em suma, cumpre discernir duas dimensões no reconhecimento: uma cognitiva e uma executiva. A primeira consiste na percepção do outro na sua condição humana e mercê de uma operação intelectual, de um silogismo - como membro de uma comunidade em que lhe corresponde uma esfera de liberdade autónoma, diferentemente do que sucede com outros seres animados e inanimados. Essa conquista 
perceptiva e intelectual deve traduzir-se em tábuas de comportamento apropriadas ao trato com seres humanos. A nossa conduta respeitosa para com eles enquanto seres capazes de se autodeterminar deve estar regulada por normas. 0 direito dá forma a uma síntese estável e duradoura entre essas dimensões discerníveis analiticamente e cristalizar-se-á numa certa organização do Estado com um executivo que monopoliza todos os poderes disponíveis e com sentinelas do seu exercício. A vontade geral encontra-se assim desavinda e o povo só pode ser soberano se for induzido a isso: seja como tribunal entre os éforos acusadores e o executivo acusado, seja em caso de traição do eforato à sua tarefa de controlo. Então, ou o povo comparece de imediato e unanimemente como juiz supremo de todos os representantes, ou apoia a convocação dos éforos naturais (uma segunda acepção de eforato), isto é, pessoas privadas que se insurgiram contra o contubérnio entre o macropoder e o contrapoder ${ }^{13}$. Por conseguinte, é só nestas situações de emergência que o povo é propriamente soberano, legislador. Mas a legitimidade desta circunstância extraordinária é muito questionável. $\mathrm{O}$ interdito do Estado conduz à suspensão de todo o ordenamento jurídico, à completa abolição da lei, pelo que se abre assim a perigosa possibilidade de que se introduza furtivamente a juridicização de um cenário não jurídico. Por outro lado, convém recordar que no estado normal da res publica não existe a "comunidade,... nenhum povo, nenhum todo" como actor ou interlocutor (GA I/3, 452).O caso excepcional extravasa o estado normal, um estado de hibernação da cidadania ${ }^{14}$. Com o apelo do eforato (seja como órgão supervisor ou como pioneiro na sublevação) o povo põe à prova a sua soberania, isto é, a sua existência política; a res publica regressa à arena da sociedade civil, mas os seus verdadeiros demiurgos são os éforos. É soberano quem, no estado de excepção, em caso de necessidade, renuncia à soberania legal e, no estado normal, à democrática, à republicana, à auto-legisladora. Ao falar-se de soberania, não se quer dizer a soberania popular da lei fundamental, mas sim a soberania supralegal que se garante a si mesma existencialmente.

A política remata a ciência do direito ${ }^{15}$ com duas atribuições: uma geral (a aproximação entre Estado de direito e Estado real) e uma específica (o desenho do mecanismo de designação dos líderes). A eleição dos éforos acaba por descambar numa selecção. Os escolhidos, os que são chamados a conduzir o destino de uma nação, são a nomenclatura dos sábios.

31 Se reconstruíssemos a árvore genealógica da política, vislumbraríamos laços imediatos com o direito que, por sua vez, depende hierarquicamente da Doutrina da Ciência -a philosophia prima que contém o elenco de princípios que irriga as ciências particulares, materiais. Não é uma mera transposição unidireccional dos princípios para campos concretos, pois, como um bumerangue, retorna na presença desses fundamentos e dá lugar a uma dupla repercussão, esclarecedora e dinamizadora. Por um lado, a aplicação dos primeiros fundamentos a determinados terrenos serve para clarificar a índole, o alcance e a dialéctica dos mesmos. Assim, por exemplo, o Direito Natural refuta a exegese solipsista da Doutrina da Ciência ao distinguir o Eu absoluto, como princípio supremo, do Eu individual, como conceito derivado e recíproco, e fá-la refulgir como uma filosofia da intersubjectividade ${ }^{16}$. Por outro [lado], essa projecção material da philosophia prima pode promover uma "expansão ulterior da Filosofia Transcendental" (GA III/4, 406). Essa promoção foi por vezes frenada e torpedeada por circunstâncias alheias (recordese as querelas em que se viu implicado). 
32 Num plano inferior sedimentam-se os saberes que medeiam entre a ciência pura e experiência sob a forma de uma aplicação dos princípios cunhados nas ciências primeiras e materiais à empeiria. No catálogo destas ciências bifrontes, anfíbias, aplicadas, conta-se a política, que franqueia "a aplicação da doutrina pura do direito a determinadas constituições estatais existentes".

Governar é uma «arte da razão». Daí ser uma disciplina inventiva e bifocal; um conhecimento montado sobre os princípios e os dados permite-lhe instituir-se como observatório a partir do qual [pode] detectar as próprias carências, mas também em oficina de reparação e de criação; encerra um propósito rectificativo e um factor de inovação. A política não é nem determinável inteiramente a priori nem uma mera adequação aos factos, mas realça, isso sim, o irrenunciável primado da filosofia e do sábio. Os saberes materiais serviam tanto para desfazer más compreensões da Doutrina da Ciência como para indicar o desdobramento inconcluso do sistema. A política assume esse duplo papel: esclarece as aporias internas e externas (contratualismo/organicismo, simetria humana/assimetria estamental, governo das leis/governo dos homens, representação/carisma) e amplia o horizonte dos princípios. A política fichteana é a execução da doutrina do direito, mas não se trata de uma aplicação ipso facto. A arte da política faz uso de figuras quiliásticas, activistas, velociferinas, mas também [de figuras] dilatórias, homeostáticas, que, tal como em Kant, maldizem a impaciência e louvam o esforço assintótico.

34 Mas Fichte submete Kant a um novo exame. Em primeiro lugar, a globalização da economia não vai proporcionar a paz, antes se converte num catalisador do saque internacional e do expansionismo militar. Em segundo lugar, com a Revolução Francesa, o povo mostrou aos homens que lhes é possível dar a si mesmos uma constituição jurídica ligada à antevisão de um federalismo. Esta prova de autodeterminação permite acalentar a esperança de que a humanidade se despeça do atavismo da guerra ao serviço do progresso. Não obstante, a França acabou por recorrer a um general, Napoleão, que neutralizou as tensões internas com um intervencionismo externo agressivo. A ameaça de ruína para o Estado provém das suas ânsias de expansão, não da tendência para a contenção. Para Fichte, uma das tarefas irrenunciáveis da filosofia estriba-se em pensar a política e em pensar contra ela. Depois de uma longa caminhada triunfal da economia do monopoly que menosprezou políticos e política, sejam bem-vindos os políticos à política.

Sem dúvida que nos Discursos à Nação Alemã se produz, senão uma viragem, pelo menos um hiato cujo vestígio se entrevê em muitos debates actuais e na facúndia dos demagogos. Estes invocam, num primeiro momento, uma comunidade de valores, a judaico-cristã, tão hermeticamente fechada que os heterodoxos e dissidentes não encontram, já desde o princípio, lugar algum no seu seio. Num momento ulterior a comunidade axiológica homogénea é fundida com os direitos fundamentais de cidadania ao ponto de [se] tornar imperceptível a diferença elementar entre normas constitucionais e valores culturais. [É] neste estratagema [que] reside o escândalo das disputas sobre a cultura hegemónica ${ }^{17}$, uma vez que já não é a carta magna que constitui aqui o marco regulador da convivência dos cidadãos, mas antes a comunidade de valores imaginada. A característica formal da nacionalidade é substituída pelo critério da pertença cultural. Tão-pouco um passaporte [ocidental] ajudaria um muçulmano no que fosse, pois um cidadão sem mancha legal sê-lo-ia unicamente enquanto membro da comunidade de valores judaico-cristã. 
36 A tentação a que todos solenemente resistem, mas em que é fácil cair ou reincidir, consiste em reduzir o Estado de direito a uma comunidade nacional, [em reduzir] o Rechsstaat a Volksgemeinschaft. No presente, A. Honneth condenou a equiparação entre reconhecimento e política de identidade ${ }^{18}$, e Martha C. Nussbaum faz do reconhecimento dos outros cidadãos como pessoas com os mesmos direitos que nós (ainda que sejam de raça, religião, género ou orientação sexual diferente) uma aptidão que todo o país que deseje fomentar a democracia ${ }^{19}$ deverá inculcar nos seus habitantes. A "patologia da repugnância" tem como eixo central a bifurcação do mundo entre o "puro" e o "impuro": a construção de um "nós" sem quaisquer defeitos e de um "eles" com miasma infecciosa. É provável que não possamos gerar pessoas imunes a todo o tipo de manipulação mas podemos, isso sim, cultivar uma pedagogia que combata a estigmatização.

37 Ainda que Fichte coadjuve nolens volens a culturalização (e inclusive a nacionalização) dos direitos a partir da equação etnocêntrica - tergiversada ideologicamente - entre germanidade, ter carácter e liberdade, também contribui com uma solidez convincente para o contrário. $O$ apelo recíproco à livre espontaneidade é ao que chama educação (GA I/3, 347-348), isto é, a exortação à auto-actividade livre, o intercâmbio de determinações à autodeterminação. Aqui descobrimos a intersubjectividade canónica. $\mathrm{O}$ isolamento, a discriminação e a massificação constituem as suas figuras truncadas, patológicas, e, consequentemente, diminuem o processo de humanização; só da interacção solidária e da comunicação recíproca se pode esperar que a humanidade se cumpra em cada um dos seus membros. Não se trata só de ver como é que integramos os que vêm de outras culturas (em que é que terão de mudar ou quais os nossos costumes que hão-de respeitar), mas também de que eles nos permitam compreender o que deve mudar numa ordem de coisas que tendemos a naturalizar e, por isso, a passar por alto no que toca à sua contingência. A coisificação, toda a determinação [que nos parece] estranha, é um esquecimento do reconhecimento constitutivo do humano lapso a que nem sempre o próprio Fichte se pôde furtar.

É já um lugar-comum afirmar que no final da década de 1980 se produz uma mudança de paradigma na teoria social, ou pelo menos uma passagem da ideia de redistribuição para a de reconhecimento: "Enquanto o primeiro conceito está ligado a uma ideia de justiça que tem como objectivo a criação de igualdade social através da redistribuição de bens que garantem a liberdade, o segundo conceito define as condições para uma sociedade justa através do objectivo do reconhecimento da dignidade ou integridade individuais de todos os seus membros" ${ }^{20}$. Distribuição e respeito deixariam de rimar e a cacofonia acabaria por beneficiar a segunda constelação conceptual que alguns interpretaram de maneira simplista como o ocaso da era social-democrata e o começo do auge neoliberal. Não foi só na Alemanha que surgiu uma controvérsia interessante sobre a fiscalidade numa democracia avançada - tema intimamente ligado ao da distribuição ou à igualdade de bens. Nos Estados Unidos (recordemos as queixas do multimilionário Warren Buffett por não poder pagar mais impostos por causa da legislação tributária do seu país, que beneficia escandalosamente as rendas mais altas) e na França (o famoso taxez-nous dos gauleses endinheirados) também se suscitou publicamente esta questão. A diferença estriba-se no seguinte: no caso germânico, este assunto foi objecto de debate académico e jornalístico, e dois dos seus melhores espadas vieram a público brandindo cada um o seu arsenal de argumentos num duelo sugestivo. Refiro-me a Peter Sloterdijk e a Axel Honneth. o primeiro assume o papel de instigador 
de uma desobediência tributária ao apelar a uma espécie de revolta anti-fiscal contra o Estado social; e o segundo alertando para o perigo que representam para a democracia [os] intelectuais dessa laia e as suas proclamações.

Dito muito sucintamente, Sloterdijk denunciaria a elefantíase do Estado impositivo, insaciável na sua voracidade colectora e expropriadora que hipoteca o futuro através de um endividamento descontrolado no presente. A semelhante "cleptocracia estatal" com vocação intervencionista e reminiscência absolutista só cabe resistir mediante a sedição dos contribuintes, isto é, por meio da abolição da tributação obrigatória e da sua substituição por donativos voluntários. Para Honneth, porém, a redistribuição económica constitui um pilar fundamental da democracia, a aplicação material dos seus princípios à sociedade. A utopia que aqui se vislumbra é a de uma tributação à discrição do cidadão. Enquanto a contribuição for feita por imperativo legal, estaremos, no máximo, numa época de Iluminismo, mas não numa época ilustrada da sociedade civil. É mister sair desta menoridade mais própria do paternalismo, que capitulou diante das tradições prescriptiva-absolutista e expropriadora-socialista. A redução do cidadão a consumidor e a sujeito fiscal secou as esperanças democráticas e Sloterdijk é favorável a que se proceda à drenagem do conceito obsoleto de emancipação, a arejá-lo numa atmosfera renovada em que o exercício da responsabilidade (ou a excelência, outro "alias" dessa noção amulética) nos redima da nossa subserviência e nos exorte a viver plenamente conscientes numa comunidade para o bem-estar da qual contribuímos ao seguirmos unicamente o nosso critério: "só uma ética da dádiva pode ajudar a superar a estagnação actual da cultura política contemporânea" ${ }^{21}$. Esta exortação à vida bemaventurada sob o signo da filantropia ou da caridade como uma fórmula capaz de solucionar os deficit conjunturais ou estruturais da nossa sociedade já foi perspicazmente injuriada por um dos ídolos de Fichte: Lessing. Para este, os benfeitores não estão interessados em sarar as feridas sociais, em erradicar as desigualdades e a marginalização; antes sucede que, para além de sucumbirem à tentação da vanglória, com as suas práticas supererrogatórias não pretendem eliminar definitivamente as situações de dependência ou de injustiça, porventura tão-só atenuá-las e, em última análise, perpetuá-las, porque a heteronomia é a razão de ser da filantropia, a ambrósia do mecenato ${ }^{22}$. Com obras de caridade não se consegue que cada homem se responsabilize pela [condução da] sua vida, máxima aspiração do Iluminismo.

Fichte combina ambos os ingredientes na sua Filosofia Política através de uma espécie de síntese entre reconhecimento de esferas de acção e repartição da propriedade na sua significação pristina de acção ou trabalho. Há uma citação instrutiva a este propósito: "Cada um dá ao corpo protector a sua contribuição: dá o seu voto para a nomeação dos magistrados, para a segurança e garantia da constituição; entrega a sua contribuição determinada em forças, em serviços, em produtos naturais ou em dinheiro, símbolo universal do valor das coisas. Mas não se dá a si mesmo por inteiro, nem [dá inteiramente] o que lhe pertence, pois, nessas condições, o que lhe sobejaria para que o Estado, por sua vez, lhe prometesse protecção? ... É só com o acto mediante o qual efectua esta contribuição que cada um faz parte do soberano. Num Estado livre, isto é, num Estado que tem um eforato, inclusive os impostos são exercícios da soberania" (GA I/4, 16).

41 Essa contribuição permite a instituição de uma comunidade política como totum e não só como compositum. $\mathrm{O}$ contrato social não fica reduzido a um argumento explicativo da génese histórica de um Estado, antes nos orienta sobre o modo como se deve conservar 
a comunidade assim instaurada. Ao contribuirmos, somos soberanos, cidadãos de um Estado livre, mas contribuir significa preeminentemente votar e tributar ${ }^{23}$. A contraprestação do Estado pelo cumprimento do pacto é a inviolabilidade da propriedade, mas tal conceito lança uma ponte entre [a] ordem jurídica e [a] ordem económica ${ }^{24}$. O direito propõe-se [estabelecer] a delimitação das esferas de acção económicas, a divisão do trabalho, o que suscita novas aporias (a pedante unidimensionalidade da especialização e o autismo profissional, vg.) e, por sua vez, novas tentativas de solução das mesmas.

Recordemos o episódio com que iniciámos a nossa conferência. A Alemanha, a Europa desfaz-se, desmorona-se. Só que agora o comunismo, como inimigo a abater, foi destronado e substituído pelo multiculturalismo, e a receita para combater esse mal, que para os ultras conduz ao suicídio cultural da identidade europeia, é a delimitação e discriminação do outro. Há dois tipos de homens: nós, os cristãos, os patriotas do Ocidente, os europeus indígenas, e os outros, os estrangeiros, [os] que tentam destruir a Europa e os seus habitantes nativos, os seus povoadores originários ${ }^{25}$.

43 O estereótipo do fichteanismo navegou entre a Cila de um arauto da liberdade e a Caribde de um inspirador do totalitarismo. Contudo, a partir da sua teoria do reconhecimento cumpre fazer um diagnóstico frutífero das patologias da modernidade e uma crítica dos seus desenvolvimentos defeituosos; e nele a autocrítica é o afluente mais caudaloso da crítica. O reconhecimento cimenta uma liberdade social, pois todos querem sentir-se afirmados, respeitados e promovidos nas suas metas pelos outros. Tal relação deve ser simétrica. $O$ direito é a condição da liberdade compartilhada. Este modelo serve para identificar progressos e retrocessos na sua realização. As perversões ou a apropriação indevida do direito são causadas pelas pretensões unilaterais de monopolizar esse campo da liberdade. A absolutização do direito, por exemplo, descambaria numa juridicização e burocratização exasperantes de todos os âmbitos da vida. Por isso convém não passar em claro outras visões possíveis do mundo. $\mathrm{Na}$ modernidade reconhecem-se avanços no que respeita à família (paradoxalmente, não na sua concepção fichteana). No seu seio cresceu a consciência do valor do reconhecimento recíproco. Testemunham-no a igualdade de direitos dos cônjuges ou a consideração e o trato respeitoso que a infância [nos] merece. Ou no âmbito da economia e do Estado: o mercado já não é a promessa de uma experiência da liberdade, a mão invisível e providencial que assegura o proveito geral; em todos os implicados deve poder frutificar a consciência de uma complementaridade recíproca e de um fomento mútuo de aspirações e capacidades. Fichte não ignora a questão de fundo que subjaz à disputa entre Sloterdijk e Honneth, isto é, a atrofia de um aparato administrativo que parasita o esforço dos cidadãos. E responde a esse desafio com uma tentativa séria de racionalizar a sua engrenagem.

Uns continuarão a ver nele um inextirpável deficit democrático e outros a genuína encarnação da soberania republicana. Mais além deste espartilho maniqueísta, quando, com Fichte a contraluz, faço a mim mesmo a sempre premente pergunta sobre as tarefas da filosofia, hoje ocorrem-me pelo menos quatro: 1) a distância crítica perante a linguagem e as imagens, perante a demagogia e a propaganda, com vista a tornar transparente a tensão entre conteúdos programáticos e a sedução mediática e evitar assim a infantilização da cidadania; 2) a conjuração da ameaça que paira sobre as democracias pela sua tendência irrefreável tanto para confundir a vontade geral com a vontade de todos, e inclusive para substituir a primeira pela última, quanto para o 
carácter auto-referencial e endogâmico da política, para a sua profissionalização, que converte num interesse prioritário a própria carreira privada dos nossos representantes públicos e a usurpação (habilmente mascarada como representação) dos cidadãos; 3) a necessidade de uma esfera pública não moldada pelos meios de comunicação de massas, tão propensos a doutrinar; e 4) a crítica da economia política para fazer face às injustiças nacionais e globais. No fundo, as máculas episódicas de um filósofo não têm por que erodir a sua fecundidade e a sua vigência que, no caso de Fichte, radicam em ter assinalado os motivos do desassossego não só do seu tempo mas especialmente do nosso e do que há-de vir, incertezas que ainda nos dão que pensar e que constituem um desafio permanente.

\section{NOTAS}

1. Na décima terceira edição (Munique: DVA, 2010) [o autor] introduz algumas correcções: agora, [é] só «a longo prazo» [que] a enorme feracidade de emigrantes muçulmanos representa uma ameaça para o «equilíbrio civilizacional na Europa envelhecida». Foi suprimida uma passagem em que se aludia às «imperfeições genéticas» dos emigrantes vindos do Próximo Oriente. 0 líder do SPD (Partido Social-Democrata Alemão), Sigmar Gabriel, considera um despropósito aquela parte do livro em que o autor fundamenta geneticamente o fracasso na ascensão dos emigrantes (e não só deles) e descreve os estratos da sociedade como o produto final da selecção biológica. Sigmar Gabriel vê no livro um «guia para a criação de humanos».

2. Recordemos, a título de exemplo de um nacionalismo exclusivo e excluinte, as palavras do seu Discurso oitavo: "Só ele [o alemão] é capaz do amor verdadeiro e racional à sua nação" (RDN, GA $\mathrm{I} / 10,198)$. Em épocas de crise nacional, Fichte torna-se uma figura intelectual pujante. Dois momentos culminantes dessa vigorosa actualização e instrumentalização do fichteanismo (especialmente de uma versão simplificada e distorcida dos seus Discursos) são 1914, em que este autor emerge inaugurando uma filosofia do germanismo (Deutschtumsphilosophie), e 1933, em que aparece como fonte de um renascimento étnico, irracional do pangermanismo. Posteriormente a essas datas e até hoje não faltaram as leituras racistas deste pensador.

3. BB, GA I/1, 292-293. E. Fuchs ("Fichtes Stellung zum Judemtum", em: Fichte-Studien, 2 (1990), pp. 160-177) contrapõe essa mensagem sinistra ao imperativo da tolerância que Fichte formula nessas mesmas páginas: "Não constranjas nenhum judeu contra a sua vontade e não permitas que tal aconteça quando estás em perfeitas condições para impedi-lo. Tu deves-lhe isso, absolutamente. Se ontem comeste e, tendo fome, não tens pão mais do que para hoje, dá-o ao judeu que ao teu lado tem fome e que ontem não comeu. Ao procederes assim, farás muito bem". Fuchs contextualiza este passo infame [que se pode ler] acima com o intuito de refutar o suposto anti-semitismo fichteano (refutação que sustenta com diversos episódios da vida do filósofo). Nesse tramo das Contribuições destinadas a rectificar o juízo do público sobre a Revolução Francesa defende-se o direito inalienável de um indivíduo a abandonar o Estado e demonstra a sua plausibilidade com o facto, que nada tem de terrível, da existência de um Estado dentro de um Estado, como é o caso do judaísmo.

4. I. Kant. Gesammelte Schriften (AK), Berlim, Walter de Gruyter, 1922 ss., XXIII, 455-456 (em: Kant, ed. de R. R. Aramayo, Barcelona: Península, 1991, p.183). 
5. Vejam-se o meu «Estudio introductorio» a Fichte, Biblioteca de Grandes Pensadores, Madrid: Gredos, 2013, e A. RENAUT, Le système du droit. Philosophie et droit dans la pensée de Fichte, Paris: PUF, 1986.

6. O catálogo de autores que participaram no debate sobre o paradigma do reconhecimento é extenso: Robert Williams, Charles Taylor, Ludwig Siep, Paul Ricoeur, Axel Honneth, Judith Butler, Seyla Benhabib, Nancy Fraser, ...

7. Fichte recorre a uma instituição do mundo grego, se bem que assinalando as devidas diferenças. Procurou-se o que pudesse actualmente corresponder ao eforato e falou-se do Tribunal Constitucional e do Provedor da Justiça (o próprio Fichte compara-o aos tribunos do povo romanos) (GA I/3, 449). É um paralelismo remoto.

8. J.G. Fichte, Rechtslehre, Meiner: Hamburgo, 1980, p.153-154.

9. Allgemeine Literatur-Zeitung, 20.11.1798, p.462.

10. A contribuição de Friedrich Schlegel, Ensaio sobre o conceito de republicanismo. A propósito do escrito de Kant «Para a paz pepétua» surgiu em 1796 na revista Deutschland, editada por J.F. Reichardt, uma das personalidades mais detestadas na Alemanha pelo seu apoio inquebrantável à França. O ensaio foi rejeitado previamente em três ocasiões pelo editor do Philosophisches Journal, Niethammer, que, uma e outra vez, instou Schlegel a introduzir modificações (E. Behler, Einleitung a Kritische Friedrich-Schlegel-Ausgabe, vol. VIII, Munique, 1966, pp XXVII ss.). Por outro lado, há que ter em conta que o Philosophisches Journal tinha publicado a recensão do opúsculo kantiano que Fichte assinara.

11. GA I/3, 456-457. "Que ninguém cuide que as nossas Constituições imperfeitas devem ser melhoradas de uma [só] vez, mediante um salto. Isto deve acontecer pouco a pouco; e no que me diz respeito, a regra deste progresso será indicada numa ciência completamente diferente: a política« (ibid.; cf. Kant, $A K$ VI, 355).

12. Tal como Rousseau, Fichte esmera-se por deslindar a vontade geral da vontade de todos (GA $\mathrm{I} / 3,400)$.

13. Diferentemente dos outros, os éforos naturais não são eleitos e rebelam-se contra o eforato eleito por este abusar de um modo flagrante da sua autoridade.

14. I. Maus fala com frequência do "extremo deficit democrático em Fichte" em comparação com o contratualismo democrático da Aufklärung ("Die Verfassung und ihre Garantie: das Ephorat (§§ 16, 17 und 21)", em: J.G. Fichte. Grundlage des Naturrechts. ed. J.-Ch. Merle, Berlin: Akademie Verlag, 2001 , pp. 139, 146, 154). Sobre a tese contrária, de que a síntese republicana de Fichte é "uma forma de representar o conceito de democracia", veja-se A. Renaut, op. cit., p. 417. Percebe-se o interesse de C. Schmitt na doutrina do eforato.

15. À política compete resolver questões tais como a forma de governo ou de soberania identifica-as, diferentemente de Kant-, o modo de eleger os governantes e os éforos, a organização da assembleia do povo, os sistemas de votação, etc. (F. Oncina Coves, "Derecho político y derecho a la política en el Fichte de Jena", en: J.-Ch. Goddard et J. Rosales (eds.), Fichte et la politique, Milão: Polimetrica, 2008, pp. 177-193). Em O Estado comercial fechado (1800)[, Fichte] reitera a incumbência da política: "No Estado real não se trata somente, como ocorre no Estado racional, das exigências do direito; antes, de saber que parte das exigências do direito são exequíveis nas condições [que estão] dadas" (GA I/7, 51).

16. Na sua carta a Friedrich Johannsen de 31 de Janeiro de 1801, confessa-lhe: "A minha Doutrina da Ciência publicada [a de 1794/1795] ostenta muitas marcas da época em que foi escrita e da maneira de filosofar, que ela seguia, que correspondia ao seu tempo. Por isso resulta mais obscura do que uma exposição do idealismo transcendental teria necessidade de ser. Bem mais recomendáveis são os primeiros capítulos do meu Direito Natural e da minha Ética..." (GA III/5,9; cfr. GA I/7, 153-154). Esta superioridade especulativa do Direito Natural em relação à Grundlage der Wissenschaftslehre [havia já sido] afirmada [por Fichte] na sua correspondência com Reinhold, de 21 de Março e de 4 de Julho de 1797 (GA III/3, 58, 69). 
17. Th. Assheuer, «Die neuen Feinde. Das Gerede von der 'christlich-jüdischen Leitkultur' schürt den Fremdenhass», em: Die Zeit, 21.10.2010, p.47.

18. A. Honneth, Das Ich im Wir. Studien zur Anerkennungstheorie, Frankfurt a.M.: Suhrkamp, 2010. Veja-se «Die transzendentale Notwendigkeit von Intersubjektivität», em: J.G. Fichte. Grundlage des Naturrechts. ed. J.-Ch. Merle, Berlin: Akademie Verlag, 2001, pp.63-80. Outros autores que se ocuparam criticamente desta questão em Fichte são p. ex. Düsing, E., Intersubjektivität und Selbstbewußtsein. Behavioristische, phänomenologische und idealistische Begründungstheorien bei Mead, Schütz, Fichte und Hegel. Köln: Dinter, 1986; Helmuth, G. (ed.), Selbstbehauptung und Anerkennung. Spinoza - Kant - Fichte - Hegel. St. Augustin: Academia, 1990; Siep, L., Anerkennung als Prinzip der praktischen Philosophie, Freiburg/München: Alber, 1979; Praktische Philosophie im Deutschen Idealismus, Frankfurt am Main: Suhrkamp, 1992; Wildt, A., Autonomie und Anerkennung. Hegels Moralitätskritik im Lichte seiner Fichte-Rezeption. Stuttgart: Klett-Cotta, 1982.

19. Nussbaum, M., Sin fines de lucro. Por qué la democracia necesita de las humanidades, Buenos Aires/ Madrid: Katz, 2010, p.48, 61, 72-73.

20. Honneth, A., Reconocimiento y menosprecio. Sobre la fundamentación normativa de una teoría social, Madrid: Katz, 2010, p. 10. Cf. Fraser, N. \& Honneth, A., Umverteilung oder Anerkennung? Eine politisch-philosophische Kontroverse. Frankfurt am Main: Suhrkamp, 2003.

21. Sloterdijk, P., Ira y tiempo, Madrid: Siruela, 2010. Veja-se a resenha de Manuel Arias Maldonado, "El caso Sloterdijk", em: Revista de libros, no 171, Março, 2011.

22. A respeito disto, são imprescindíveis os seus Diálogos para franco-mações (1778-1780).

23. No capítulo IV d'O Estado comercial fechado defende que os impostos (Abgaben) servem, entre outras coisas, para cobrir as necessidades do governo, o ensino, a formação e a defesa da nação (GA I/7, 73). O que é mais: n'O Fundamento do Direito Natural, o Estado deve garantir a todos os cidadãos o direito ao trabalho e à subsistência (isto é, a que se possa viver daquele), pelo que, para além de supervisionar e regular a vida económica, é uma instituição assistencial (Unterstützungsanstalt) (GA I/3, 213-215).

24. O nexo entre $O$ Fundamento do Direito Natural (1796-1797) e O Estado comercial fechado (1800) não só está sustentado pelas respectivas e óbvias afinidades temáticas mas também pelas meramente nominais. O subtítulo da última [obra] reza: Um ensaio filosófico como apêndice à Doutrina do Direito $e$ como exemplo de uma política a seguir no futuro. Na sua carta ao editor J. G. Cotta de 16 de Agosto de 1800 di-lo com claridade meridiana: "Acabo de expor uma ideia que guardava comigo desde a redacção do meu Direito Natural: estabelecer a constituição comercial necessária para um Estado completamente conforme ao direito e à razão e mostrar por que via o Estado real poderá aceder a tal constituição. [...] $\mathrm{O}$ interesse científico deste ensaio reside no facto de constituir a transição das investigações sobre Direito Natural segundo a Doutrina da Ciência para as investigações políticas segundo esta última" (GA III/4, 285-286).

25. Segundo o programa terrorista do genocida norueguês Anders Breivik, por trás do multiculturalismo acha-se o "marxismo cultural" (Th. Assheuer, E. Finger und O. Topçu, "Bomben für das Abendland. Eine Analyse von Anders Breiviks Programm", em: Die Zeit, 28.07.2011).

\section{RESUMOS}

This article deals with Fichte's concept of "recognition" in its multiple dimensions and implications. The present exposition firstly aims at highlighting the link between mutual 
interaction and intersubjectivity, on the one hand, and, on the other hand, the intrinsic relationship between recognition as criterion for otherness and the faculty (or power) for identifying the presence of freedom in the sensible world. From the perspective of recognition I then proceed to a revision of main concepts of social and political life such as: customs and values, rights and duties, aspirations and abilities and action and property. I will argue that "recognition" is not only a fundamental concept of the Doctrine of Knowledge, but also a concept by means of which a constructive criticism of contemporary philosophy and political and economic crisis can be exerted.

\section{ÍNDICE}

Keywords: Fichte, recognition, democracy, anti-Semitism, patriotism, State

\section{AUTORES}

\section{FAUSTINO ONCINA COVES}

Universitat de València 